\title{
CHALLENGES OF MOBILE JOURNALISM IN DIGITAL MEDIA AGE
}

\begin{abstract}
Owing to the constant technology improvement and innovation, new ways of reception and creation of media content have developed, leading to the redefining of known communication processes. In this new digital media age, characterized by new features such as convergence, mobility and interactivity, mobile journalism emerged as a new journalistic form-challenging relation between creators and recipients of media content. Even though the idea of user-generated media content that can be instantly shared and broadcasted using small mobile devices sounds like a multi-beneficial concept, this model still faces many challenges. In practice, numerous questions have arisen, such as ethics, reliability and quality of such content as well as acceptance and implementation into professional newsrooms. Therefore, the aim of this article is to review an academic approach to this topic, backed by practical examples, in order to place mobile journalism into a complex modern media system and evaluate its potential in the context of future development.
\end{abstract}

Key words: mobile journalism, convergence, user generated content, newsrooms, journalism, new media

\section{Introduction}

The development of technology has been affecting the media industry for centuries now. Each new discovery in that field has provided new ways to create and deliver information to end users and helped the shaping of new media. For instance, the internet era has redefined the existing communication models with users as passive recipients of media content without a significant input on their part. Owing to new platforms and modern devices, the audience today not only has the access to the content that was previously unavailable in the traditional media era, but it also has an opportunity to create and publish its own content. In that way a new media environment is created in which traditional and new media coexist fueled by the audience that tends to be more active in creating, delivering and receiving bits of information.

The internet era affected not only the audience and its role, but it also influenced all types of media. Traditional media are still in the ongoing process of adapting to a

\footnotetext{
${ }^{1}$ Received September 2020 / Accepted December 2020

${ }^{2}$ email: dusan.aleksic@filfak.ni.ac.rs
} 
new online environment, while facing the competition from the online only media and the online content created by users themselves. Therefore, in order to stay relevant on the market, they need to follow the development of new technology closely and try to implement modern achievements in websites, social media profiles and other internet platforms that serve as an extension of their media. That includes the user generated content as well, which is not new in media discourse (blogs, forums, comments, etc.). However, this type of content has also been improved over the years, so now it can exist independently or as a part of both traditional and new media. According to Ran Wei, no other medium connects people better than a telephone, which opens countless possibilities in the communication field. "The portability of mobile phones makes "connected co-presence" anywhere any time. Even though individuals may be still spatially separated, they are disconnected from one another" (Wei, 2013: 52).

Due to those characteristics, speed became the most important factor in news distribution, which opened a whole new field in journalistic practice based on new technology - mobile journalism. Creation of this new form opened a possibility for both the audience members and professional journalists to produce their own media content, broadcasting live videos or sending bits of information almost simultaneously with the ongoing event. Yet, the process of implementation into professional news rooms or wider acceptance has not been without obstacles. That is why one of the main goals of this article is to give insight into challenges and perspectives of mobile journalism in modern age and modern media systems.

\section{New media landscape - new audience}

In recent years, mobile journalism has emerged as one of the most popular ways in the media sphere to publish stories almost simultaneously with the ongoing event. In other words, not only did the media change, but the audience changed as well. The Internet development during the last decade of the 20th century and the implementation of internet services into numerous social spheres (entertainment, economics, media...) inspired theorists to talk about "second media age", which represents a total transformation of current mass media theories, because now special attention is paid to interactivity aspect, meaning that the audience is no longer just a recipient of media content, but they get an opportunity to become creators. This approach changed the concept of mass media and the way in which the reception of such content had been perceived to that point. Thanks to the domination of newspapers, radio and television, the mass media communication process was mainly viewed as one-way. As David Holmes points out, for that reason "second media age" theories are especially inspirational from the perspective of communication science (Holmes, 2005). Active role of the audience as well as their full potential, according to Ivana Stamenković, has been recognized by critical studies of culture: "Recognizable by their critical spirit, cultural studies have evolved as an opponent to the existing dominant paradigm, bringing the correctness of the social order and constructed 
meanings into question" (Stamenković, 2020: 31). Therefore, we can say that new technology creates a new audience which, according to modern theories, can be marked as participatory. As Sonia Livingstone claims, "the audience is becoming more and more participatory, while its forms of participation are becoming more mediated in the media" (Livingstone, 2013: 4). Talking about the participatory aspect, we need to take social media into consideration "since they are the intermediaries in a direct relationship with users, providing content variety: from political to entertainment, at the same time giving them the opportunity to participate and create their own content. Because of the services they provide, we find that they can potentially influence the creation of public opinion" (Mitrović \& Obradović, 2020: 43).

Nowadays we can discuss a mobile audience that prefers mobile devices for consuming and creating content (Lopez-Garcia, Silva-Rodriguez, VizosoGarcia, Westlund, Canavilhas, 2019). Considering the rapid growth of such an audience (Reuters Institute, 2018), it is important to understand characteristics and particularities of this new communicative platform (Lopez-Garcia et al., 2019).

For instance, if an incident happens, citizens will probably capture it with a mobile device, so they could send it to authorities, transmit it live on social media platforms and/or send it to professional newsrooms. And that is where the story of mobile journalism (often shortened as MoJo) starts. Since this type of content often becomes an important source for professional media, it largely affects the role of professional journalists and the way they collect data. Thanks to mobile phones and their ever-improving features, modern journalists can produce news, photos and videos directly from the field, while maintaining every aspect of what is perceived as a quality journalistic product. That makes production a lot faster and efficient. Besides that, Sajid Umair notes the following: "Mobile phones also provide a potential means to retrieve up to date or contextual information through the mobile internet or context-aware services" (Umair, 2016: 1).

The impact of the inclusion of mobile journalism into professional media field was also noted by Ivo Burum in his book "Democratizing Journalism through Mobile Media: The Mojo Revolution" in which he stated: "This new, more diverse expression of power located in more specialized subfields of journalism becomes part of the broader information ecosphere in a changing communication (literary) field" (Burum, 2016: 36).

\section{Mobile journalism - perspective and challenges}

Even though there is no strict definition of mobile journalism in the academic field, many authors tried to extricate its characteristics in order to differentiate it from multimedia journalism and establish its own working area. For now, this phenomenon lacks a permanent name, so Lopez-Garcia and others (Lopez-Garcia et al, 2019) noted that some authors called it mobile digital journalism (Campbell, 2007), mobile news journalism (Forsberg, 2001), and mobile journalism (Briggs, 2007; Quinn, 
2000; Pavlik, 2001; Castells, 2006). For instance, Ran Wei defines mobile media as "primarily as a personal, interactive, internet-enabled and user-controlled portable platform that provides for the exchange of and sharing of personal and non-personal information among users who are inter-connected" (Wei, 2013: 52). When it comes to practice, Aljazeera Media Training and Development Centre in its publication titled Mobile Journalism defines this form as "the process of gathering and delivering news using a smartphone or tablet. It is a trend in news covering and broadcasting, having the potential to become the new standard in journalism practice, especially to report breaking news" (Mobile Journalism, 2017: 2). Still, when talking about the media aspect, there are two important perspectives that should be in the focus of research - dissemination and reception of content for mobile devices and content production.

But mobile journalism is not facing challenges in academic fields only, but in practical areas as well, because it is still trying to find its place inside the media sphere. As observed by Perreault and Stanfield, "mobile journalists find themselves in a place of tension, between print, broadcast, and digital journalism and between traditional journalism and lifestyle journalism" (Perreault \&Stanfield, 2018: 331). Therefore, one of the major questions regarding this journalistic area is whether mobile journalism should be observed as a part of existing media models or as an independent entity. At the same time, the role of mobile journalists is questioned - does production completely rely on mobile devices to prepare the content for use on various platforms or is it about a content intended for mobile consumption only regardless of the device used to produce such content? Judd Slivka notices that mobile content is usually intended for social media platforms, so what should be taken into consideration is duration and the platform a content creator is aiming at. "Newsrooms want mobile video and mobile produced pieces. But they want them for social reasons. They want 10:20 pieces, not a 1:30 piece (...). If we're producing for social, we're probably producing for Twitter. And if we're producing for Twitter, we need good-enough quality, not great quality. If we're producing for Facebook, we're likely creating videos that are designed to be digested without the sound on" (Slivka, 2017). Assuming that this type of journalism does not require any special equipment, it is essentially available to everyone who possesses at least a mobile phone and internet connection. That is why it is often said that mobile journalism is the most audience driven form of journalism. That form is audience-oriented, and it engages the audience to become an essential part of the process. "The audience itself searches and retrieves information in which it is interested, and the processes of selection of the information sphere bring the audience into a universe of ideas and content created according to each individual" (Stamenković, 2020: 38).

This journalistic form becomes increasingly present in mainstream media, as mentioned by Wenger, Owens, and Thompson since nowadays digital skills are expected from journalism students to create mobile journalism content. In their research, the mentioned authors point out that mobile skills were required in only $2 \%$ of job postings related to the journalism field. But, in 2013, this number increased 
to $23 \%$ and even that "lags behind mobile's prominence in newspaper and online job ads" (Wenger, Owens, and Thompson 2014, 138). When we take this data into account, it should come as no surprise that authors such as Bivens (Bivens, 2008) describe mobile technology as a game changer for all types of media. Development of mobile news services and mobile applications, as noted by Westlund (Westlund, 2012), affected numerous newsrooms around the globe - both traditional and digital to form omnipresence strategies, so their content could become accessible anytime, anywhere and on as many devices possible. To use this potential community, mojo authors with necessary skills become part of local media, while students get a great opportunity to prepare themselves for a career in journalism's converged space. Mojo skills can also help print journalists to adapt to new technological environments, so they could interact professionally with the global media sphere. Of course, this sphere is not reserved for everyone who owns a mobile phone. For instance, Burum states that: "The degree to which citizens can use global networks to create local voices will largely depend on access to technology and skills that enable them to create empowering UGS 3 " (Burum, 2016: 37).

In order to try to place mobile journalists and mobile journalism into a complex media system, Perreault and Stanfield conducted a research using an online survey that was sent to mobile journalists from different media hubs. Results showed that these journalists saw an opportunity for better storytelling, ability to report in a timelier nature which allowed them to become community and breaking news reporters. Additionally, there is an ability to share information easily through various platforms while working remotely. Here, interactivity, which has always been proclaimed as one of the chief characteristics in the context of new media, gets an additional dimension. Speaking of interactivity, we usually refer to the connection between a reader and a story. However, this research indicates that this characteristic goes one step further in mobile journalism. Because of that, we can also discuss a new connection - the one between a reader and an author. Thanks to this improved process of interactivity, the change of roles is also possible, so, at a certain moment, a recipient can become a content creator and vice versa. Taking this into consideration, mobile journalism can be perceived and accepted as an alternative journalistic form that offers non-mainstream content that, one would think, was hidden on purpose. One of the examples is China, the country that is known for constant news censoring, so demand for various forms of mobile journalism is high. "The widespread use of mobile tweeting (e.g., microblogs accessible via the Smartphone) in news dissemination in China provides a case in point [...]. The total of microblog users in China increased from 63.11 million in 2008 to 195 million in 2010. Currently 34 percent of China's mobile internet users have a presence in the cyber blog sphere through a mobile Twitter account, which offers them an alternative channel of uncensored news in China's tightly controlled media environment. Several high-profile corruption cases were first reported by mobile tweets posted by average citizens" (Wei, 2013: 53). Nowadays, employees in professional newsrooms often get

\footnotetext{
${ }^{3}$ user-generated stories
} 
iPhones or mobile devices with the Android interface that help them report the story. "In addition, rather than using the mobile only for traditional reporting, journalists have also used applications for live video streaming (e.g., Bambuser) and live blogging (e.g., Disqus)" (Westlund, 2013: 16).

Nevertheless, mobile journalists feel the need to position themselves as high as possible on the crowded market and become someone that audience will turn to. That is why the aspect of interactivity is an important factor. Therefore, those journalists can deliver stories the audience wants in the best possible way. So, the goal here is a quality product that aligns with ethical and professional standards of traditional journalism. To achieve this, authors need to ensure that their content is reliable and fulfills highest technical standards in terms of quality regarding video, photography, audio and other multimedia content. They also need to make sure that bits of information they are sharing are ethically obtained and that the privacy of all involved in creating certain media content is respected. Only with these preconditions can we discuss mobile journalism as a professional journalistic form with all the unique features it contains. This characteristic is, among others, an original approach to the concept of journalism genres. Even though those authors often use professional media discourse by labeling news as breaking, hard or soft news with a scale of importance, there is no strict division in terms of genres in mobile journalism. Such content is labeled as storytelling, which represents a hybrid of common genres (news, article, interview and story) and it is combined with various audio and visual elements. Those stories "can range from those of personal experience, stories of learning, and messages for social justice to historical anecdotes, documentaries and digital video reports [...] It becomes evident that digital storytelling, the traditional personal story enhanced by images, narrative voice and music, has grown into several very distinct genres" (Garrety \& Schmidt, 2008: 916). Such storytelling allows a usage of subjective narrative, helped by multimedia aspect, which is characterized by concise, direct discourse that does not shy away from the emotional tone. Some of those stylistic aspects were discussed in an article by Ivan Cvetanović and Vladeta Radović: "The freedom to express unconditionally through language belongs to the individual. In this case, the journalist should have the unconstrained awareness about his responsibility to himself and to the world. Such freedom is gained through courage to express a certain attitude despite the subjective feeling of being constrained" (Cvetanović \& Radović, 2017: 4).

When it comes to mobile journalism, one of its most positive aspects relies on the fact that it can overcome censorship and find the way to deliver information to the audience. This is especially important in local areas where journalists are easy targets of political and financial pressure. Burum thinks that "a local Indigenous mojo field can potentially serve to enable accurate local reportage by creating a specialized local journalistic subfield of Indigenous reporting" (Burum, 2016: 36).

As a negative aspect, it was pointed out that those newsrooms see this type of work as a burden (Perreault \& Stanfield, 2018: 8). This indicates that managers of traditional media are aware of popularity, influence and necessity of such content, 
but that they are not ready to invest in professional equipment showing they are not fully ready to acknowledge legitimacy and necessity of such journalism. As noted in the research mentioned before: "Newsrooms perceive the mobile as a burden because newsrooms may be required to modify the workflow in order to adapt it to the new habits of consumption" (Perreault \& Stanfield, 2018: 8). This problem is especially evident in newsrooms management consisting of older people who are not willing to adapt to and accept changes in the journalistic field. Some mobile journalists provided an explanation for this phenomenon saying that it represents "additional burden that does not drive news consumers back to the original medium" (Perreault \& Stanfield, 2018: 11). In this way a tension is created between journalists and their management, because mobile journalists tend to follow and implement new technological achievements into their work, so they could be better journalists and position themselves better on the market. On the other hand, they still need to comply with the rules of their respective newsrooms as it is their primary job.

But, aside from resistance, the authenticity of mobile generated content should also be questioned. For instance, the vacuum that puts mobile journalism between amateurs and professionals in the media system has increased the competition between them, so in efforts to publish certain content as soon as possible, especially in the era of live transmitting, we can easily get the product that can fool and manipulate the audience. "The videos and photos may be tampered or manipulated, or the content may be provided in such a way that it conveys half or wrong information. Videos may be spread by the opposite parties and provide completely false information" (Umair, 2016: 5).

Certain newsrooms embraced UGC. The local example is online portal Južne vesti which is centered in Niš (Southern Serbia) and publishes mobile journalism products regularly. Mojo products consist of short video clips with subtitles encoded, followed by textual description. The authorship is divided. Some of these clips are done by newsroom journalists themselves, while others are produced by citizens who send material to the mentioned newsroom. The content is published after editorial checking and potential interventions. When it comes to citizens' content, those are usually video documents of local "incidents" that affect their lives (riots, demolition of property, conflicts with authorities etc.). Their journalists publish similar topics along with unusual stories (acts of individuals that, by the estimate of the editorial board, deserve to be heard about). Južne vesti publish this content under video section on their website and, for now, there is no specific place for such content. When they post these stories onto official social media accounts, they are preceded by hashtag \#MoJo. Frequency of such content is 2-3 stories per month, so we can easily conclude that such content has still not found its permanent place on this website.

Nevertheless, certain newsrooms are reluctant to embrace mojo. Some of the reasons for this are content quality and ethical implications that may arise from citizens who post the content that could potentially harm the brand or reputation of a media organization. Moreover, some pointed out that UGC would require additional resources for supervising and managing such content before publication (Westlund, 2012). 


\section{Conclusion}

Ethical principles, reliability (e.g., spreading fake news) are among unsolved issues in a domain of so-called professional journalism even today. Therefore, in a crowded market of mobile journalists, it is hard to distinguish whose work aims at professional reporting and to understand the weight of responsibility for publicly shared content. In addition to that, it is hard to determine whose goal is simply a domain-commercial and popularity aspect, or what the motives for spreading fake news and disinformation are. For that reason, the second aspect continuously reopens some of the dilemmas stressed in this article and represents the main obstacle for full acceptance and approval of mobile journalism.

There is no doubt that new media not only changed the media landscape in terms of genres, style, multimedia content, speed, but it also provided a way for faster spreading of content below every professional and ethical standard.

Yet, we cannot deny the fact that these new media forms represent the media future and that these new forms play an important role in the democratization of the public sphere. That is why an education, especially in the media field, represents an important factor. In times when there is a thin line between media content creators and media content recipients, it is important to learn how to create and how to recognize quality media content. Considering how frequent the changes in the media field are, the necessity of permanent learning becomes evident - through both formal and informal education. Before moving to technical aspects, those who tend to become media content creators need to learn basic ethical principles and realize the weight of responsibility for publicly shared content - and today, there are multiple credible sources that could help journalists reach that goal.

Traditional newsrooms survived through the decades thanks to accepting and adapting to changes in the field of media technology. Technology did not change the media alone - it also changed the audience that now has different demands and priorities. In order to offer good enough content for the new audience, professional newsrooms need to embrace new media forms such as mobile journalism that are already thriving in alternative media landscapes. That kind of collaboration would surely lead to quality incensement of such content. Moreover, the difference between good and bad content would be more visible and transparent. By implementing new forms, professional newsrooms would not only offer bits of information in a way that fits a new audience, but it would also create a model that is more permanent and economically sustainable, which is one of the most important factors for the future media development. 


\section{References}

Aljazeera Media Training and Development Centre (2017). Mobile journalism. Available at: https://institute.aljazeera.net/sites/default/files/2018/mobile\%20journalisn $\% 20$ english.pdf (accessed on 11. 1. 2020.)

Bivens, R. K. (2008). The Internet, mobile phones and blogging: How new media are transforming traditional journalism. Journalism Practice, 2(1), 113-129. https://doi. org/10.1080/17512780701768568

Briggs, M. (2007). Periodismo 2.0. Una guía de alfabetización digital para sobrevivir y prosperar en la era de la información. Austin: Knight Center for Journalism in the Americas

Burum, I. (2016). Democratizing journalism through mobile media: the mojo revolution. Routledge.

Campbell,S. (2007). A cross-cultural comparison of perceptions and uses of mobiletelephony. New Media \& Society, 9(2), 342-363. https://doi.org/10.1177/1461444807075016

Castells, M. (2006). Mobile communication and society: A global perspective. Cambridge, MA: MIT Press

Cvetanovich, I., \& Radovich, V. (2017). Language and style in the time of global mass media. Russian Linguistic Bulletin, (4 (12) 2017), 3-7. https://dx.doi.org/10.18454/ RULB.12.27

Forsberg, K. (2001). Mobile newsmaking. Göteborg University.

Garrety, C., \& Schmidt, D. (2008, March). The evolution of digital storytelling: from enhanced oral tradition to genres for education. In Society for Information Technology \& Teacher Education International Conference (pp. 916-921). Association for the Advancement of Computing in Education (AACE).

Holmes, D. (2005). Communication Theory: Media, Technology and Society. SAGE.

Livingstone, S. (2013). The participation paradigm in audience research. Communication Review, Vol 16 (1-2), pp. 21-30. ISSN 1071-4421 DOI: 10.1080/10714421.2013.757174

López-García, X., Silva-Rodríguez, A., Vizoso-García, Á. A., Westlund, O., \& Canavilhas, J. (2019). Mobile journalism: Systematic literature review. Comunicar. Media Education Research Journal, 27(1). https://doi.org/10.3916/C59-2019-01

Mitrović, M. \& Obradović, N. (2020). Searching for public interest on the Internet. Media Studies and Applied Ethics, 1 (1), 41-52. https://doi.org/10.46630/msae.1.2020.04

Pavlik, J. (2001). Journalism and new media. New York: Columbia University Press. https:// doi.org/10.7312/pavl11482

Perreault, G., \& Stanfield, K. (2019). Mobile Journalism as Lifestyle Journalism? Field Theory in the integration of mobile in the newsroom and mobile journalist role conception. Journalism Practice, 13(3), 331-348. https://doi.org/10.1080/17512786. 2018.1424021

Quinn, C. (2000). mLearning: Mobile, wireless, in your-pocket learning. Line Zine, Fall. https://bit.ly/2DcUveg

Slivka, J. (2017). The things we carry and don't. Available at: https://www.juddslivka.com/ philosophy-and-gear-packs-2017/ (accessed on 11. 1. 2020) 
Stamenković, I. (2020). Online audience in digital media network. Media Studies and Applied Ethics, 1 (1), 29-40. https://doi.org/10.46630/msae.1.2020.05

Umair, S. (2016). Mobile reporting and journalism for media trends, news transmission and its authenticity. Journal of Mass Communication and Journalism, 6. https://doi. org/10.4172/2165-7912.1000323

Wei, R. (2013). Mobile media: Coming of age with a big splash. Mobile Media \& Communication, 1(1), 50-56. https://doi.org/10.1177/2050157912459494

Wenger, D., Owens, L., \& Thompson, P. (2014). Help wanted: Mobile journalism skills required by top US news companies. Electronic News, 8(2), 138-149. https://doi. org/10.1177/1931243114546807

Westlund, O. (2012). Guest editorial: Transforming tensions; legacy media towards participation and collaboration. Information, Communication \& Society, 15(6), 789795. https://doi.org/10.1080/1369118X.2012.694899

Westlund, O. (2013). Mobile news: A review and model of journalism in an age of mobile media. Digital journalism, 1(1), 6-26. https://doi.org/10.1080/21670811.2012.740273

\section{IZAZOVI MOBILNOG NOVINARSTVA U DIGITALNOM MEDIJSKOM DOBU}

Rezime: Zahvaljujući konstantnom tehnološkom napretku i inovaciji, razvili su se novi načini recepcije i kreacije medijskuh sadržaja, što je dovelo do redefinisanja poznatih komunikoloških procesa. U ovom novom digitalnom medijskom dobu, koje, između ostalog, karakteriše konvergencija, mobilnost $i$ interaktivnest, mobilno novinarstvo se javlja kao nova novinarska forma koja utiče na relaciju između kreatora i recipijenta medijskih sadržaja. Iako ideja o medijskim sadržajima koje korisnik generiše i publikuje pomoću mobilnih uređaja u teoriji zvuči kao višestruko koristan koncept, ovaj model se suočava sa brojnim izazovima. U praksi su se pojavila brojna pitanja, poput etičnosti, pouzdanosti i kvaliteta takvih sadržaja, kao i koliko su profesionalne redakcije spremne da ih prihvate i implementiraju. Zbog toga, cilj ovog rada jeste da pruži uvid u akademski aspekt proučavanja ove teme, uz korišćenje praktičnih primera, kako bi se mobilno novinarstvo pozicioniralo u kompleksnim savremenim medijskim sistemima i kako bi se procenio njegov potencijal u kontekstu daljeg razvoja.

Ključne reči: mobilno novinarstvo, konvergencija, korisnički medijski sadržaji, redakcije, novinarstvo, novi mediji 